\title{
ПРИНЦИПЫ ПРОВЕДЕНИЯ ЭКОЛОГО-ЦЕНОТИЧЕСКОГО АНАЛИЗА ФЛОР СОСУДИСТЫХ РАСТЕНИЙ АЗИАТСКОЙ АРКТИКИ И СУБАРКТИКИ
}

\author{
Поспелов И. Н ${ }^{1}$, Поспелова Е. Б. ${ }^{2}$ \\ ${ }^{1}$ Институт проблем экологии и эволющии РАН им. А. Н. Севериова, г. Москва \\ ${ }^{2}$ ФГБУ «Заповедники Таймыра», г. Норильск \\ E-mail: pleuropogon@gmail.com; parnassia@mail.ru
}

\begin{abstract}
На примере п-ова Таймыр и сопредельных территорий рассмотрены методы проведения эколого-ценотического анализа флоры, включающей 943 вида и подвида. Приведены характеристика и анализ систематической и географической структуры выделенных 9 ландшафтнофитоценотических свит и 23 эколого-ценотических групп, указаны возможности дальнейшего использования результатов для проведения флористического районирования и флорогенетического анализа.
\end{abstract}

Ключевые слова: флора, сосудистые растения, Таймыр, эколого-ценотический анализ, ландшафтно-фитоценотические свиты, эколого-ценотические группы.

DOI: $10.34078 / 1814-0998-2020-2-49-58$

\section{ВВЕДЕНИЕ}

Любой достаточно полный список сосудистых растений, независимо от того, составлен ли он для отдельного ключевого участка (локальная либо конкретная флора) или для более крупной территории ранга флористического района, подпровинции или даже провинции в системе флористического районирования, нуждается в разностороннем анализе. При сравнительном анализе локальных и региональных флор, как правило, в первую очередь проводятся анализы их таксономической и географической структуры. Для арктических и субарктических флор, где растения находятся близ предела существования, большое значение имеют также результаты эколого-ценотического анализа, т. е. выявления групп видов растений, сходных по экологическим потребностям (теплу, влаге, снеговому укрытию, характеру субстрата и т. д.), предпочитающих местообитания, близкие по степени проявления этих факторов и приуроченных к определенному типу растительности.

Ландшафты и сопутствующий им растительный покров Таймыра в границах Таймырского района Красноярского края представлены как равнинными, так и горными типами, территория простирается от северотаежной подзоны до полярных пустынь, что обусловливает высокое разнообразие растительного покрова. Флора сосудистых растений по последним данным включает

(С Поспелов И. Н., Поспелова Е. Б., 2020
943 вида и подвида (Поспелова, Поспелов, 2007; Флора Таймыра, 2018).

В предлагаемой работе мы приводим методику проведения эколого-ценотического анализа флоры и некоторые примеры использования его результатов.

\section{МАТЕРИАЛ И МЕТОДЫ}

Эколого-ценотическая структура флоры обусловлена не только климатическими факторами, но и в гораздо большей степени ландшафтной структурой территории - характером ее геологического строения и рельефа, определяющим перераспределение тепла и влаги, геохимические потоки и почвообразовательные процессы. В основу проведения эколого-ценотического анализа нами было положено выделение групп экологически и экотопически сходных видов с учетом их активности в экотопах, относящихся к разным ландшафтам и занятых разными растительными сообществами. Соотношение видов этих групп во флорах разного ранга - от парциальных до зональных, является важной характеристикой, позволяющей судить не только об общем характере флоры, но и о генезисе и путях ее становления. При их выделении мы придерживались двухступенчатой системы, при этом, в отличие от классического «формационного» анализа (Толмачев, 1974), за основу принималась ландшафтная структура территории, а уже потом на нее «накладывались» характерные фитоцено- 
хоры разного ранга со свойственными им ценофлорами. Для этого использовались комплексные ландшафтные карты разного, в зависимости от размера территории, масштаба, составленные на основе собственных маршрутных наблюдений по предварительно отдешифрированным космическим снимкам. По данным более 1000 ландшафтно-геоботанических описаний и маршрутных записей, а также обширных гербарных сборов, для каждого вида с определенной степенью достоверности выявлялись его экологические свойства, ценотическая и ландшафтная приуроченность. При отнесении вида к той или иной группе по каждому фактору мы имели в виду условия того экологического оптимума, при котором популяции вида достигают пика жизненности, становятся высокоактивными.

На первом этапе виды группировались в крупные объединения, включающие виды, экологически и исторически связанные с соответствующими экологически контрастными крупными ландшафтными выделами. Территориальный ранг этих выделов различен - от ландшафта или даже класса ландшафтов (горы) до урочища (водоемы). Им соответствует определенный тип (или несколько близких типов) растительности, сформированный свитами видов, в наибольшей степени свойственных этим выделам. Эти группы, генетически и экологически связанные с определенными типами ландшафтов и свойственной им растительностью, мы назвали ландшафтнофитоценотическими флористическими свитами (ЛФС). При их выделении учитывались факторы среды, определяющие их состав, а также приуроченность к господствующим фитоценохорам приблизительно ранга типа растительности, которые выделялись по господствующей биоморфе эдификаторного яруса. На территории Таймыра и его южной периферии можно выделить 9 ЛФС: горную мезоксеропетрофитную, тундровую гигромезофитную, болотную гигрофитную, кустарниково-луговую, приморскую гигрогалофитную, лесную мезофитную, эрозиофильную, водную гидрофитную, адвентивную. В какой-то мере они соответствуют флороценотическим комплексам Б. А. Юрцева и Р. В. Камелина (1991), но, в отличие от последних, во главе угла при их выделении стоит приуроченность к конкретному классу (типу) ландшафта, в пределах которого могут встречаться несколько фитоценохор разного ранга (при одной преобладающей), но приспособленных к существованию именно в этом ландшафте.

\section{РЕЗУЛЬТАТЫ И ОБСУЖДЕНИЕ}

На первый взгляд, ЛФС соответствуют основным типам растительности, распространенным в пределах тундровой зоны (Александрова,
1977; Юрцев, 1991), однако не всегда. Так, в горную ЛФС входят не только горно-тундровые, но и горно-луговые и горно-лесные виды, которые обнаруживали наибольшее обилие и активность в горах, где имеется оптимум их произрастания. Болотные и луговые виды, связанные с интразональными и «интраландшафтными» экотопами, одинаково широко распространены как в горах, так и в равнинных тундрах, вплоть до полярнопустынной зоны, и в лесотундре. Ряд видов лесной свиты проникает на север далеко за границу лесотундры. Вообще амплитуда произрастания многих видов крайне широка, поэтому отнести их к конкретной свите порой трудно, но все же некоторый оптимум произрастания, связанный с крупными ландшафтными выделами, имеется почти у всех. Даже эвритопные виды имеют свой ценотический и экологический оптимум, выражающийся в максимальной парциальной активности в одном из выделов, а в другие они заходят только при наличии соответствующих экологических ниш.

Дальнейшее разделение ЛФС проводилось на основании экологического анализа флоры с учетом широты экологической амплитуды и активности видов в каждом ландшафтном выделе на основе полевых ландшафтных и геоботанических описаний и комплексных ландшафтноэкологических карт. При отнесении конкретного вида к той или иной эколого-ценотической группе (ЭЦГ) учитывалась его встречаемость и обилие в сообществах конкретных экотопов. Эти группы объединяют растения, которые в силу их экологии, генезиса и ценотической приуроченности сопряжены с группами экотопов, свойственными каждой ЛФС (23 ЭЦГ). При этом экотопы могут быть разного ранга - от микроэкотопов (делли, бугры и полигоны болот) до мезоэкотопов, занимающих большие площади (плакорные осоково-моховые тундры, обширные болотные комплексы). Соответственно и фитоценохоры, приуроченные к ним, могут иметь ранг от группировки до ассоциации и даже формации, но при этом составляющие их виды обладают сходной экологией, выражающейся в близких значениях потребностей в основных факторах внешней среды - степени и режиме увлажнении, сумме активных температур в данном местообитании, снеговом укрытии, химизме почвы, гранулометрическом составе субстрата. Следует подчеркнуть, что, как и в случае экологического анализа, речь идет исключительно о «поведении» конкретного вида растения на территории Таймыра, потому что в других регионах могут проявляться и другие его особенности, как можно видеть хотя бы из сравнения экологических и экологоценотических свойств одних и тех же видов на Таймыре и, к примеру, на Полярном Урале. Так, в 
горах юга Таймыра Sanguisorba officinalis встречается исключительно в кустарниках и на лугах долин, на Урале она распространена и обильна на горных лугах вплоть до границы лесного пояса, а в долинах на лугах редка. Строго лесной на плато Путорана папоротник Rhizomatopteris montana на Полярном Урале растет исключительно в западинах скал, т. е. становится горным эрозиофильным видом. Можно предположить, что смена экотопической приуроченности обусловлена в данном случае одинаковым проявлением экологических факторов (свет, влажность, тепло), оптимальных для конкретного вида, в разных ландшафтах и в разных районах Крайнего Севера.

I. Тундровая ЛФС. Центральная, зональная свита, включает широко распространенные тундровые виды. Большинство видов политопные, их амплитуда охватывает экотопы с тундровыми глеевыми почвами более тяжелого гранулометрического состава - от супесчаных до глинистых, от слабокислых до нейтральных, от умеренно влажных до слабо переувлажненных. Произрастают они в моховых или кустарничково-травяномоховых тундрах, на буграх и валиках болот, в горах на участках, где коренная порода перекрыта чехлом мелкозема, на низкогорьях юга Таймыpa. Свита включает 4 ЭЦГ:

собственно тундровая. Объединяет повсеместно распространенные виды широкой амплитуды, в основном мезофильные, мезотрофные, мезохионные; оптимальные экотопы - плоские водораздельные поверхности с зональными осоково-моховыми и (кустарниково)кустарничково-осоково-моховыми тундрами (Carex arctisibirica, Minuartia arctica, Draba pilosa, Salix reptans и др.);

лугово-тундровая (луговинная). В нее входят виды, предпочитающие дренированные, нейтральные, слабо оглеенные или неоглеенные почвы, требовательные к снеговому укрытию и умеренному увлажнению, обитающие преимущественно на мелкоземах, иногда слегка ощебненных, избегая лишь кислых торфянистых почв (Astragalus umbellatus, Polemonium boreale, Draba hirta, Potentilla hyparctica и др.). Оптимальные экотопы - дренированные бровки берегов рек, задернованные склоны холмов, высокие речные террасы с разнотравно-мохово-кустарничковыми и разнотравно-кустарничковыми тундрами, обычны в предгорьях и низкогорьях Бырранги;

болотно-тундровая. Включает гигромезо- и мезогигрофильные виды, более олиготрофные, чем в предыдущей группе, переносящие периодически застойное увлажнение. Их экотопы слабо дренированные, сырые, несколько вогнутые водоразделы с начинающимся термокарстом, делли; глубокие моховые ложбины в плакорных тундрах, выпуклые и плоские бугры и валики болот (Eriophorum vaginatum, Juncus biglumis, $\mathrm{Ca}$ lamagrostis holmii, Salix fuscescens). Преобладающие сообщества - сырые пушицево-осоково-моховые и кустарниково-осоково-моховые тундры;

нивальная. Мегахионные, микротермные, гигромезофильные, мезоэвтрофные виды, избегающие кислых почв (Saxifraga hyperborea, Phippsia algida, Ranunculus sabinii, R. pygmaeus и др.). Их экотопы - периферии нивальных ниш у подножий склонов, сырые слабовогнутые горные плато верхнего пояса, на равнине - подножия байджарахов, склонов долин ручьев, днища оврагов, илистые отмели в недавно спущенных озерных котловинах.

II. Горная ЛФС объединяет виды, наиболее обычные для горного ландшафта или встречающиеся только в горах, как на севере территории, так и на юге. Они приспособлены к хорошо дренированным, щебнистым, мелкоземистощебнистым, глыбовым субстратам нейтральной или основной реакции $(\mathrm{pH}>6.5)$, на которых формируются почвы дернового ряда - от бедных горных примитивных органогенно-щебнистых до богатых горных дерновых. Свита включает 5 ЭЦГ:

горно-эрозиофильная. Объединяет преимущественно ценофобные, микротермные, ксерои мезоксерофильные, петрофильные, олигохионные, нейтро- и базифильные виды, обычные как в горах Бырранга, так и в горах юга Таймыра, но отсутствующие или неактивные на равнинах (Dryopteris fragrans, Lesquerella arctica, Potentilla subvahliana, Poa abbreviata и др.). Их оптимальные экотопы - каменистые горные плато верхнего пояса, с куртинными (покрытие менее $15 \%$ ) кустарничковыми и кустарничково-травяными тундрами, травяными, эпилитно- и эпигейнолишайниковыми группировками, глыбовые развалы, подвижные осыпи, скальные останцы;

горно-тундровая. К ней относятся виды, экологически сходные с предыдущими, но менее ценофобные, несколько более требовательные к теплу, богатству почвы и снеговому укрытию; по отношению к составу субстрата их скорее можно отнести к гемипетрофитам (Carex rupestris, Oxytropis nigrescens, Potentilla uniflora и др.). Оптимальные экотопы - горные плато среднего и нижнего пояса, на равнине - камы и массивы каменистых бугров, дренированные тундры выпуклых водоразделов и бровок склонов с медальонными дриадовыми тундрами;

горно-луговая. Представлена термофильными, ксеромезофильными и мезофильными, преимущественно петрофильными, петро-псаммофильными и гемипетрофильными видами, требовательными к относительно богатым, дренированным, глубоко протаивающим почвам (Si- 
lene paucifolia, Potentilla prostrata, Hedysarum dasycarpum). Оптимальные экотопы - горные склоны благоприятных экспозиций, скальные полки с кустарничково-разнотравно-злаковыми луговинными тундрами и лугами;

горно-криофитно-степная. Включает гемипетрофильные, мезоксерофильные и термофильные растения остепненных разнотравно-злаковых и злаковых лугов - фрагментов реликтовых криофитных степей (Юрцев, 1981). Приурочены к теплым сухим щебнистым склонам с нейтральными дерновыми почвами, иногда слаборазвитыми, часто карбонатными - Phlojodicarpus villosus, Potentilla prostrata, Calamagrostis purpurascens и др. Более обычны в горах юга Таймыра, на равнинах практически отсутствуют, встречаясь лишь изредка в южных тундрах;

горно-лесная. В нее входят только виды гор юга Таймыра (плато Путорана, Анабарское и Котуйское), обитающие в основном на каменистых залесенных склонах, иногда на прогалинах среди горных лиственничных редин. В равнинных редколесьях очень редки. Это петро- или гемипетрофильные, гемиэвтрофные виды, требовательные к теплу и условиям заснеженности (Juniperus sibiricus, Diphasiastrum alpinum, Gymnocarpium jessoense, Festuca altaica и др.).

III. Болотная ЛФС объединяет гигрофильные виды, оптимум произрастания которых приурочен к торфянистым и торфяным почвам со слабокислой и кислой реакцией, формирующимся в долинах и осушенных озерных котловинах. Включает 3 ЭЦГ:

собственно болотная. Олиготрофные гигрофиты и мезогигрофиты, приуроченные к тундрово-болотным комплексам - развитым полигонально-валиковым и плоскобугристым болотам, на юге - грядово-мочажинным болотам и плоскобугристым торфяникам, встречаясь там на всех элементах комплексов, кроме обводненных участков, - в травяно-моховых и травяных сообществах полигонов и мочажин, кустарниково-травяно-моховых на буграх и валиках (Eriophorum russeolum, E. gracile, Carex chordorrhiza, Ranunculus lapponicus и др.);

водно-болотная. Включает гигрофиты, характерные местообитания которых - берега обводненных полигонов, озер, стариц, где они образуют порой чистые или 2-3-видовые заросли. Это растения илисто-песчаных, слегка заторфованных субстратов, обычные в массивах болот, в долинах четочных ручьев, вокруг термокарстовых озер, на отмелях низкой поймы рек (Equisetum fluviatile, Hippuris vulgaris, Pleuropogon sabinii, Arctophila fulva, Ranunculus pallasii и др.);

лугово-болотная. В эту группу входят мезотрофные гигрофиты. В тундрово-болотных комплексах они произрастают в мокрых, слабо замо- ховелых (но не обводненных) полигонах и термокарстовых просадках, в сырых заболоченных днищах небольших ручьев и оврагов, в арктических тундрах - в термокарстовых массивах на водоразделах, на юге - в заболоченных лесах по полянам и окраинам болот (Hierochloe pauciflora, Dupontia fisheri, Pedicularis albolabiata и др.).

IV. Кустарниково-луговая ЛФC, наиболее объемная по составу, объединяет мезотрофноэвтрофные, в основном мезофильные и гигромезофильные термофильные виды разнообразных травяных и кустарниковых сообществ, развитых на дренированных почвах преимущественно дернового ряда. Произрастают в долинах на терраcax и речных берегах, редко встречаясь в плакорных тундрах и редколесьях. В нее входят 4 ЭЦГ:

собственно луговая. Представлена мезофильными, мезоэвтрофными видами дренированных почв дернового ряда, преимущественно песчаных и супесчаных, требовательными к летнему теплу и хорошей заснеженности (Festuca richardsonii, Oxytropis adamsiana, Papaver pulvinatum, Cerastium maximum и др.). Оптимальные экото-пы - долинные луга высокой поймы и низких террас рек и крупных ручьев, песчаные прирусловые валы, высокие береговые склоны (яры), зоогенные луга на песцовых поселениях;

лугово-кустарниковая. Включает виды, произрастание которых связано с долинными и приречными лугами, но они обязательно встречаются и иногда доминируют в нижнем ярусе долинных кустарников (Trisetum litorale, Arctagrostis arundinacea, Equisetum arvense, Ranunculus propinquus), в том числе и сами кустарники - доминанты приречных зарослей (Salix alaxensis, S. lanata). Предпочитают мелкоземистые или щебнисто-мелкоземистые грунты, нейтральные почвы легкого механического состава, неустойчивы к застойному увлажнению (но выносят периодическое заливание во время весенних и летних паводков);

гигрофильно-луговая. К этой группе относятся мезогигрофильные и гигрофильные, мезоэвтрофные и эвтрофные травы (Calamagrostis neglecta, Petasites frigidus, Chrysosplenium sibiricum, Cardamine pratensis), экологически отчасти близкие к лугово-болотным. Но, в отличие от последних, они наиболее активны не на болотах, а на сырых болотистых, часто замоховелых лугах, в сырых эвтрофных деллях, на заиленных заболоченных отмелях рек и озер, на лугах у подножий склонов, в сырых кустарниках, в минеральных горных висячих болотах, на слегка заболоченных луговых полянах в таежной зоне;

лугово-степная. Представлена мезоксерофильными и ксеромезофильными, относительно термофильными, часто умеренно кальцефильными травами и полукустарничками, довольно 
требовательными к богатству почвы, но способными расти и на бедных. Предпочитают дренированные, глубоко протаивающие, ощебненные или опесчаненные грунты, кислых субстратов определенно избегают. Сухие луговины на песчаных террасах рек и гривках высокой поймы, древних береговых валах, приречные сухие яры, реже травяные группировки на нагорных террасах, иногда сухие редколесья.

V. Приморская ЛФС. Содержит единственную ЭЦГ, в которую входят гигрогалофиты, узкостенотопные виды, произрастающие на приморских болотистых маршах (галофитных лугах) и засоленных пляжах, преимущественно приуроченных к арктическому побережью. Это виды, приспособленные к периодическому забрызгиванию и заливанию морской водой, растущие на грунтах разного состава, но предпочитающие илистые, мелкодисперсные субстраты (Carex ursina, C. glareosa, Stellaria humifusa и др.). Их общая черта - почти облигатная галофильность, по причине которой они не растут в других условиях, но здесь всегда довольно обильны.

VI. Эрозиофильная ЛФС. Объединяет виды, предпочитающие в основном, открытые, неза-

Таблица 1. Ландшафтно-фитоценотические свиты и эколого-ценотические группы во флоре Таймыра

Table 1. Landscape-phytocoenotic suites and ecologo-coenotic groups within the Taimyr flora

\begin{tabular}{|c|c|c|c|c|}
\hline \multirow[b]{2}{*}{$\begin{array}{c}\text { Ландшафтно-фитоценотические свиты } \\
\text { и входящие в них ЭЦГ }\end{array}$} & \multicolumn{2}{|c|}{ От всего списка } & \multicolumn{2}{|c|}{ От ЛФС } \\
\hline & $\begin{array}{c}\text { Кол-во } \\
\text { видов } \\
\text { в ЛФС }\end{array}$ & $\begin{array}{c}\% \text { от } \\
\text { состава } \\
\text { флоры } \\
\text { Таймыра }\end{array}$ & $\begin{array}{c}\text { Кол-во } \\
\text { видов } \\
\text { в ЭЦГ }\end{array}$ & $\begin{array}{c}\% \text { от состава } \\
\text { ЛФС }\end{array}$ \\
\hline Тундровая (T) & \multirow[t]{5}{*}{166} & \multirow[t]{5}{*}{18.0} & - & - \\
\hline собственно тундровая & & & 72 & 43.4 \\
\hline лугово-тундровая & & & 51 & 30.7 \\
\hline болотно-тундровая & & & 26 & 15.7 \\
\hline нивальная & & & 17 & 10.2 \\
\hline Кустарниково-луговая (К) & \multirow[t]{5}{*}{230} & \multirow[t]{5}{*}{24.9} & - & - \\
\hline собственно луговая & & & 88 & 38.3 \\
\hline лугово-кустарниковая & & & 74 & 32.2 \\
\hline лугово-степная & & & 32 & 13.9 \\
\hline гигрофильно-луговая & & & 36 & 15.6 \\
\hline Болотная (Б) & \multirow[t]{4}{*}{84} & \multirow[t]{4}{*}{9.1} & - & - \\
\hline собственно болотная & & & 41 & 48.8 \\
\hline лугово-болотная & & & 16 & 19.0 \\
\hline водно-болотная & & & 27 & 32.2 \\
\hline Горная (Г) & \multirow[t]{6}{*}{152} & \multirow[t]{6}{*}{16.4} & - & - \\
\hline горно-эрозиофильная & & & 41 & 27.0 \\
\hline горно-тундровая & & & 36 & 23.7 \\
\hline горно-луговая & & & 29 & 19.1 \\
\hline горно-криофитно-степная & & & 34 & 22.3 \\
\hline горно-лесная & & & 12 & 7.9 \\
\hline Лесная (Л) & \multirow[t]{3}{*}{116} & \multirow[t]{3}{*}{12.5} & - & - \\
\hline собственно лесная & & & 71 & 61.2 \\
\hline лугово-лесная & & & 45 & 38.8 \\
\hline Эрозиофильная (Э) & \multirow[t]{3}{*}{92} & \multirow[t]{3}{*}{10.0} & - & - \\
\hline отмельная & & & 30 & 32.6 \\
\hline эрозиофильная & & & 62 & 67.4 \\
\hline Приморская (П) & 13 & 1.4 & - & - \\
\hline Водная (В) & 27 & 2.9 & - & - \\
\hline Адвентивная (А) & 44 & 4.8 & - & - \\
\hline
\end{tabular}


дернованные местообитания с сомкнутыми или разреженными травяными, реже кустарниковотравяными группировками. Это ценофобы, пионеры зарастания отмелей, оползней, осыпей; они крайне редко встречаются в иных экотопах, отступая перед другими (главным образом, луговыми) видами в ходе сингенеза. По характеру предпочитаемых экотопов делятся на 2 ЭЦГ:

отмельная (аллювиально-эрозиофильная). Представлена стенотопными (реже гемистенотопными) ценофобными растениями, закрепляющимися на свежих аллювиях рек, галечниках и валунниках озер, сухих морских пляжах (Poa sublanata, Deschampsia obensis, Carex maritima, Leymus interior и др.). Предпочитают песчаные грунты, хотя встречаются и на заиленных, и на щебнистых; не переносят застойного увлажнения и закисления, к богатству почвы нетребовательны, приспособлены к механическому воздействию (вода, ветер, лед), постоянному заливанию. Встречаются как единичными экземплярами, так и довольно густыми зарослями;

эрозиофильная. Включает виды широкой амплитуды обнаженных поверхностей вне пойменных уровней: оползней, склонов оврагов, обнажений древних морских глин, илистых днищ вытекших озер. Предпочитают суглинки и супеси, хотя растут и на песках. Устойчивы к режиму периодического пересыхания, к богатству почвы нетребовательны (Puccinellia neglecta, Neotorularia humilis, Arabidopsis bursifolia, Descurainia sophioides и др.), некоторые отчетливо базифильны. Растительность представлена сложными группировками разной степени сомкнутости, сложенными этими видами с участием некоторых других.

VII. Лесная ЛФС объединяет бореальные и, реже, гипоарктические виды, заходящие в тундровую зону местами только в ее южной подзоне (Larix spp., Duschekia fruticosa, Pyrola incarnata, Equisetum scirpoides и др.). Они наиболее термофильны и нуждаются в достаточном снеговом укрытии; по отношению к увлажнению они большей частью мезофиты, но могут переносить как слегка избыточное, так и несколько недостаточное увлажнение, к гранулометрическому составу субстрата в целом нетребовательны. Включает 2 ЭЦГ:

собственно лесная. Виды этой группы генетически связаны с лесной растительностью, оптимум произрастания их в лесах, где они наиболее активны, крайне редко встречаются в других экотопах. Это деревья, а также относительно теневыносливые травы и кустарнички (Equisetum sylvaticum, Trientalis europaea, Vaccinium myrtillus и др.), кустарники нижнего и среднего ярусов (Sorbus sibirica, Salix jenisseensis). Некоторые виды этой группы изредка встречаются и в южных тундрах, но там не обильны и, скорее всего, в этой зоне являются реликтами более теплых эпох;

лугово-лесная (опушечная). Это виды луговые по своей природе, но они не выходят за пределы лесной зоны, очень редко встречаются в лесотундре. Они приурочены к лесным полянам, опушкам, вырубкам, кустарниковым прогалинам с маломощным моховым покровом, в долинах к кустарниковым зарослям поймы и прилегающих горных склонов, где произрастают вместе с лугово-кустарниковыми видами (Hystrix sibirica, Equisetum pratense, Thalictrum kemense, Galium boreale и др.).

VIII. Водная ЛФС с единственной ЭЦГ. К ней относятся погруженные прикрепленные гидрофиты (Potamogeton spp., Myriophyllum spp.), и только на крайнем юге Таймыра встречаются плавающие гидрофиты (Lemna trisulca, Utricularia spp., Ceratophyllum demersum), но крайне спорадично. Их экотопы - мелкие озера (глубина 0.51 м, очень редко до 4-5 м), обводненные мочажины болот, слабо текущие водотоки, старицы; в крупных озерах заводи и мелкие заливы. Почти все виды встречаются только в лесной зоне, реже в южных тундрах и лишь единицы проникают в типичные.

IX. Адвентивная ЛФС включает виды сорных мест в поселках, засоренных лугов и кустарников; они также слагают травяные группировки в окрестностях населенных пунктов (Polygonum aviculare, Stellaria media, Vicia sepium, Chenopodium spp.).

Каждая из свит и эколого-ценотических групп имеет специфическую систематическую структуру (табл. 2). Так, наиболее разнообразный состав семейств и родов характерен для кустарниково-луговой ЛФС, причем при некотором преобладании Роасеае и Asteraceae, остальные ведущие семейства представлены почти поровну. Так же пропорциональна семейственная структура тундровой ЛФС, только злаки здесь составляют $12 \%$ от состава. В горной ЛФС наиболее представлены Brassicaceae и Rosaceae, а в лесной - Asteraceae и Salicaceae. Более половины болотной ЛФС составляют Сурeraceae, 60\% видов эрозиофильной ЛФС представляют 3 семейства: Brassicaceae, Poаceae и Asteraceae.

Родовая структура свит более пестрая, по числу родов лидирует кустарниково-луговая ЛФС, меньше всего родов в болотной (табл. 2). Довольно специализированы только род Draba для тундровой (42\% видов рода) и горной (41\%) свит, в них же в основном сосредоточены Saxifraga (48 и $43 \%$ ), Potentilla (64\% видов рода в горной свите) и Papaver (56\% в тундровой и $31 \%$ в горной). Среди других родов можно выделить только Рuccinellia (69\% видов рода в эрозиофильной ЛФС) и Salix (41\% - в лесной). 
Таблища 2. Состав ведущих семейств флоры Таймыра в основных ЛФС (количество / процент от состава ЛФС)

Table 2. Composition of the the Taimyr flora leading families in the main landscape-phytocoenotic suites (number/percentage of the composition of the LPS)

\begin{tabular}{|l|c|c|c|c|c|c|c|}
\hline \multirow{2}{*}{ Ведущие семейства } & \multicolumn{7}{|c|}{ Ландшафтно-фитоценотическая свита } \\
\cline { 2 - 8 } & тундровая & горная & лесная & $\begin{array}{c}\text { куст.- } \\
\text { луговая }\end{array}$ & болотная & $\begin{array}{c}\text { эрозио- } \\
\text { фильная }\end{array}$ & $\begin{array}{c}\text { адвен- } \\
\text { тивная }\end{array}$ \\
\hline Poaceae & $\mathbf{2 0 / 1 1 . 9}$ & $14 / 9.1$ & $9 / 7.7$ & $\mathbf{3 5 / 1 5 . 3}$ & $14 / 9.1$ & $\mathbf{2 3 / 2 5 . 5}$ & $5 / 11.9$ \\
\hline Cyperaceae & $14 / 8.3$ & $10 / 6.5$ & $4 / 3.4$ & $10 / 4.4$ & $\mathbf{4 3 / 5 1 . 8}$ & $3 / 3.3$ & Нет \\
\hline Salicaceae & $5 / 3.0$ & $1 / 0.6$ & $\mathbf{1 2 / 1 0 . 2}$ & $4 / 1.7$ & $2 / 2.4$ & $2 / 2.2$ & Нет \\
\hline Caryophyllaceae & $13 / 7.7$ & $8 / 5.2$ & $3 / 2.6$ & $15 / 6.6$ & Нет & $7 / 7.8$ & $2 / 4.8$ \\
\hline Ranunculaceae & $7 / 4.2$ & $2 / 1.2$ & $10 / 8.5$ & $18 / 7.9$ & $\mathbf{1 0 / 1 2 . 0}$ & $3 / 3.3$ & $1 / 2.4$ \\
\hline Brassicaceae & $13 / 7.7$ & $\mathbf{2 3 / 1 4 . 9}$ & $2 / 1.7$ & $6 / 2.6$ & Нет & $\mathbf{1 4 / 1 5 . 6}$ & $\mathbf{8} / \mathbf{1 9 . 0}$ \\
\hline Saxifragaceae & $12 / 7.1$ & $7 / 4.5$ & Нет & $5 / 2.2$ & Нет & Нет & Нет \\
\hline Rosaceae & $5 / 3.0$ & $\mathbf{1 7 / 1 1 . 1}$ & $10 / 8.5$ & $6 / 2.6$ & $2 / 2.4$ & $2 / 2.2$ & Нет \\
\hline Fabaceae & $4 / 2.4$ & $9 / 5.8$ & Нет & $15 / 6.6$ & Нет & Нет & $5 / 11.9$ \\
\hline Scrophulariaceae & $9 / 5.4$ & $4 / 2.6$ & $2 / 1.7$ & $14 / 6.1$ & $3 / 3.6$ & $1 / 1.1$ & Нет \\
\hline Asteraceae & $12 / 7.1$ & $\mathbf{1 7 / 1 1 . 1}$ & $\mathbf{1 5 / 1 2 . 8}$ & $\mathbf{2 8 / 1 2 . 2}$ & $1 / 1.2$ & $\mathbf{1 4 / 1 5 . 6}$ & $\mathbf{4 / 9 . 5}$ \\
\hline Всего семейств & 31 & 31 & $\mathbf{3 3}$ & $\mathbf{4 1}$ & 17 & $\mathbf{1 7}$ & 14 \\
\hline Всего родов & 68 & 67 & $\mathbf{6 8}$ & $\mathbf{1 0 3}$ & 30 & 52 & 35 \\
\hline
\end{tabular}

Состав геоэлементов в разных свитах также специфичен. Среди широтных фракций в тундровой, горной и приморской ЛФС ожидаемо преобладает арктическая (76.52 и 77\%), но в горной более высока доля гипоарктической и бореальной фракций по сравнению с двумя другими. Бореальная фракция резко преобладает в лесной и болотной ЛФС ( 88 и $61 \%)$ и очень незначительно - в кустарниково-луговой (52\%), где арктических видов всего $18 \%$, в основном за счет гигрофильно-луговой группы.

Среди долготных групп в большинстве ЛФС преобладает циркумполярная (наиболее значительно - 85\% в приморской), остальные группы распределены относительно равномерно (рис. 1).

В кустарниково-луговой ЛФС несколько выше доля евразиатской (EA3) группы (31\%) и примерно поровну (19-20\%) представлены азиатские (АЗ), циркумполярные (Ц) и восточноазиатские (ВАЗ) виды, примерно та же ситуация и в лесной, но здесь восточноазиатских значительно меньше. Дело в том, что эта ЛФС сформирована в основном растениями, встречающимися на юго-западе Таймыра, куда далеко не все восточноазиатские виды проникают. А наибольшее значение восточноазиатские виды имеют в горной ЛФС (32\%, при $23 \%$ азиатских и минимальной, $18 \%$ роли циркумполярных). Горная свита формировалась во многом вследствие миграций ксеропетрофитных видов с востока и северо-востока. К тому же в ней наиболее высока (10\%) доля эндемичных и субэндемичных (таймырских, среднесибирских) видов, особенно в горно-тундровой и горно-эрозиофильной ЭЦГ, что подчеркивает существенную самобытность горной флоры Таймыра, в которой сосредоточена большая часть видов этих групп, а также ее более тесную связь с горной флорой северо-восточной Азии, нежели с европейской. Доля азиатско-американской группы (АЗАМ) в общем низкая, но наиболее высока она $(10.1 \%)$ в тундровой ЛФС; число видов с преимущественно американским ареалом незначительно, но относительно высока их доля в водной и эрозиофильной ЛФС (по 7\%).

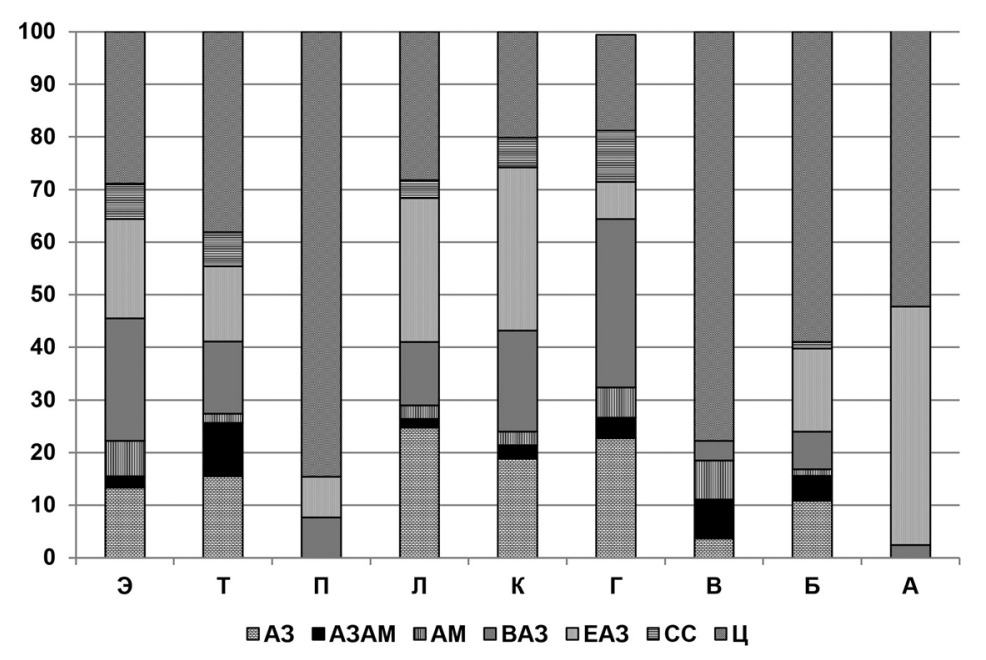

Puc. 1. Соотношение долготных групп в ЛФС (обозначения ЛФС см. в табл. 1, обозначения долготных групп см. в тексте)

Fig. 1. The ratio of longitudial groups in the LPS (for LPS designation, see Table 1; for the designation of longitudial groups, refer to the text) 
На протяжении всего широтного профиля от северотаежной подзоны до полярных пустынь соотношение ЛФС существенно изменяется, у одних доля в составе флоры зональных и подзональных полос закономерно увеличивается к северу, у других снижается, у третьих в распределении по широтному градиенту наблюдаются «пики» и спады (рис. 2). Это связано, прежде всего, с изменением набора экотопов, что, в свою очередь, обусловлено изменением климата и характера рельефа (на рис. 2 не учитывалась адвентивная ЛФС, поскольку ее роль во флоре связана не с изменениями в ландшафте, а со степенью освоенности территории).

Равномерное увеличение к северу доли в составе флоры наблюдается для приморской и тундровой ЛФС; небольшой подъем имеется для последней только в горной полосе типичных тундр за счет обилия здесь лугово-тундровых видов. Еще более он выражен на графике для горной ЛФС, где на кривой имеется 3 пика - ожидаемо в горных полосах северотаежной подзоны и типичных тундр, и в полярных пустынях, где преобладают низкогорные ландшафты. Противоположная тенденция - у прочих ЛФС, их доля во флоре постепенно снижается к югу. Только у кустарниково-луговой на графике имеется не- большой пик во флоре равнинной полосы северотаежных лесов и южных тундр, здесь наиболее широко распространены предпочитаемые видами этой свиты экотопы - долинные луга, кустарники и редины. Лесная свита закономерно снижает свое участие к северу, но в южных тундрах встречаются даже Larix spp., Ribes triste, Rosa acicularis и др., а в типичной, хотя и единично, встречены ольховник, Lycopodium dubium, Cardamine macrophylla и некоторые другие. Столь же равномерно снижается к северу участие водной свиты, а у болотной и эрозиофильной распределение довольно ровное, что и подчеркивает их связь с интразональными и интраландшафтными экотопами, присутствующими по всему профилю. Очень своеобразна кривая, отражающая распределение по меридиональному профилю видов приморской ЛФС, постепенно повышающаяся от единичных находок в южных тундрах к максимуму в арктических, преимущественно в равнинной северной полосе. Следует отметить, что распределение по меридиональному профилю ЭЦГ, составляющих свиты, может различаться соответственно разнообразию предпочитаемых экотопов, но в силу ограниченного объема мы не можем подробно рассмотреть их в настоящей работе.

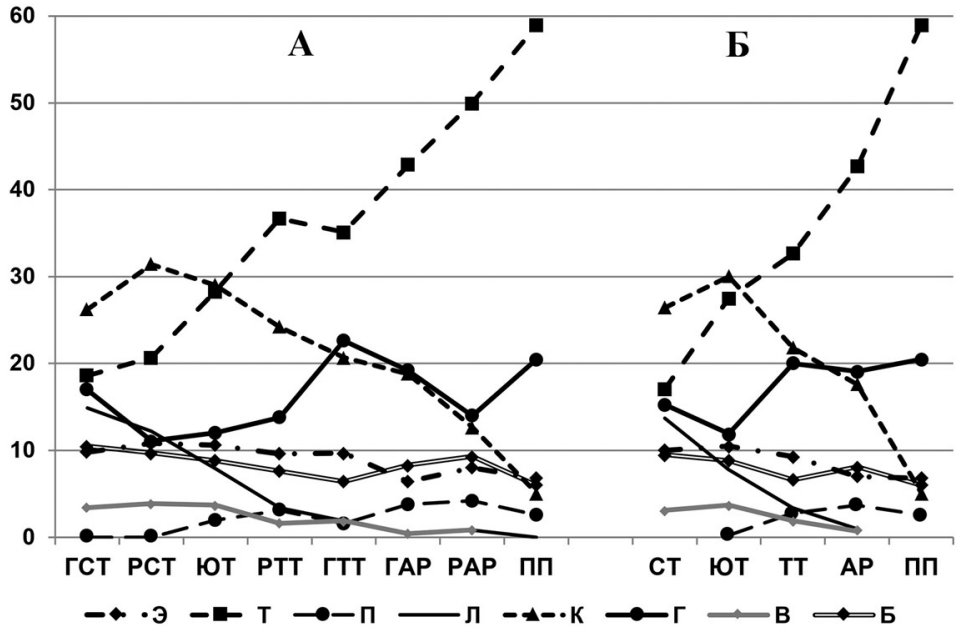

Puс. 2. Процентное содержание ЛФС в региональных флорах широтных полос (А), зон и подзон (Б) по меридиональному профилю. Пояснения к рисунку: СТ - северотаежная подзона (полосы: ГСТ - горная, РСТ - равнинная); подзоны тундровой зоны: ЮТ - южная, ТТ - типичная (полосы: ГТТ - горная, РТТ - равнинная), АР - арктическая (полосы: ГАР - горная, РАР - равнинная; ПП - зона полярных пустынь)

Fig. 2. Percentage of the LPS (landscape-phytocoenotic suites) in the regional floras of latitudinal bands (A), zones and sub-zones (Б) by the meridional profile. Explanations: $\mathrm{CT}$ - Northern taiga subzone (strips: ГСТ - mountain, РCТ - plain); the tundra zone subzones: ЮT - South, TT - typical (strips: ГTT - mountain, PTT - plain), AP - Arctic (strips: of ГАР - mountain, РАР - plain; ПП - zone of polar deserts)

\section{ЗАКЛЮЧЕНИЕ}

Проведен эколого-ценотический анализ флоры Таймырского района Красноярского края, на территории которого по результатам многолетних полевых наблюдений и литературных источников выявлены 943 вида и подвида сосудистых растений. В результате было выделено 9 ЛФС, включающих 23 ЭЦГ. По числу видов лидируют кустарниково-луговая, тундровая и горная ЛФС. По составу ведущих семейств выделяется горная ЛФС, где больше всего роль Brassicaceae и Rosaceae и болотная с преобладанием Суреraceae и Ranunculaceae. Проведен также анализ состава геоэлементов в каждой ЛФС, отмечается преобладание видов арктической фракции в тундровой и приморской, бореальной - в лесной и болотной. Среди долготных групп наиболее интересным оказалось резкое преобладание восточноазиатских видов в горной ЛФС, а циркумполярных - в приморской и тундровой.

На основании соотношения отдельных ЛФС в проанализированных списках локальных флор можно судить об их ландшафтно-зональном положении, а по соотношению разных 
ЭЦГ - о разнообразии ландшафтной структуры участка. Эти данные, наряду с особенностями географической структуры флоры, мы использовали, в частности, при проведении флористического районирования территории (Поспелова, 2010) - по соотношению ЛФС довольно четко различаются крупные выделы ранга подпровинций и округов. Достаточно информативны как различия долей видов зональных ландшафтов и составляющих их урочищ, а именно горной, лесной и тундровой ЛФС, так и интразональных долинных ландшафтов с лугами, кустарниками и болотами. Различия в соотношении отдельных ЭЦГ в большей степени наблюдаются при выявлении более мелких выделов - ранга флористических районов, особенно если учитывать не просто наличие тех или иных видов в группе, но и их активность, как сочетания встречаемости (широты экологической амплитуды) и общего уровня численности (Юрцев, 1968).

Также по эколого-ценотической структуре можно судить о генезисе, возрасте и истории региональных флор при проведении флорогенетического анализа. Так, лесные виды во флоре южных, а тем более типичных тундр могут быть реликтами голоценового термического оптимума, а лугово-лесные - следствием современной инвазии, связанной с очередным циклом потепления климата. Наличие видов приморской ЭЦГ (правда, минимальное) на отмелях оз. Таймыр (типичные тундры), скорее всего, наследие мощной морской трансгрессии во время каргинского межледниковья.

\section{ЛИТЕРАТУРА}

Александрова В. Д. Геоботаническое районирование Арктики и Антарктики. Л. : Наука, 1977. $187 \mathrm{c.}$

Поспелова Е. Б. Опыт флористического районирования Таймырского автономного округа с применением кластерного анализа // Тр. Рязанского отделения РБО. Вып. 2. Сравнительная флористика. Ч. 2. Материалы Всерос. школы-семинара по сравнительной флористике, посвящ. 100-летию «Окской флоры» А. Ф. Флерова, 23-28 мая 2010 г. Рязань : Рязанский ГУ им. С. А. Есенина, 2010. C. 234-242.

Поспелова Е. Б., Поспелов И. Н. Флора сосудистых растений Таймыра и сопредельных территорий. Ч. 1. Аннотированный список флоры и ее общий анализ. М.: Тов-во науч. изданий КМК, 2007. 457 с.

Толмачев А. И. Введение в географию растений. Л. : Изд-во Ленинград. ун-та, 1974. 244 с.

Флора Таймыра. Информационно-справочная система [Электрон. pecypc]. URL: http://byrranga.ru (дата обращения 20.10.2018).

Юриев Б. А., Камелин Р. В. Основные понятия и термины флористики. Пермь : Пермский ГУ, 1991. $80 \mathrm{c}$.

Юриев Б. А. Проблемы выделения тундрового типа растительности // Ботанический журн. 1991. T. 46, № 1. C. 30-41.

Юриев Б. А. Реликтовые степные комплексы северо-восточной Азии. Новосибирск : Наука, 1981. $168 \mathrm{c}$.

Юриев Б. А. Флора Сунтар-Хаята: проблема истории высокогорных ландшафтов северо-востока Сибири. Л. : Наука, 1968. 235 с.

Поступила в редакичю 26.11.2018 2.

Поступила после доработки 22.09.2019 2.

\title{
PRINCIPLES OF THE ECOLOGICAL-COENOTIC ANALYSIS OF THE ASIAN ARCTIC AND SUBARCTIC VASCULAR FLORAS
}

\author{
I. N. Pospelov', E. B. Pospelova ${ }^{2}$ \\ ${ }^{I} A . N$. Severtsov Institute of Ecology and Evolution RAS, Moscow \\ ${ }^{2}$ Joint Directorate of Taimyr Reserves, Norilsk
}

Exemplified by the Taimyr Peninsula and adjacent territories, methods of the ecological-coenotic analysis of flora, including 943 species and subspecies, are considered. The characteristics and the analysis of systematic and geographical structure of the allocated landscape-phytocoenotic suites and ecologo-coenotic groups are presented; the possibilities of further use of the analysis results for floristic zoning and florogenetic analysis are indicated.

Keywords: vascular plants, flora, Taimyr, ecological-coenotic analysis, landscape-phytocoenotic suites, ecocoenotic groups. 


\section{REFERENCES}

Aleksandrova, V. D., 1977, Geobotanical Zoning of the Arctic and Antarctic, Leningrad, Nauka [In Russian].

Flora of Taimyr, Information and Reference System [Electronic Resource], URL: http://byrranga.ru (Accessed 20.10.2018) [In Russian].

Pospelova, E. B., 2010, Experience of Floristic Regionalization of Taimyr Autonomous District Using Cluster Analysis, Proceeding of Russian Botanical Society Ryazan Branch, Iss. 2, Comparative Floristic, Part 2, Materials of All-Russian School-Seminar Devoted to the $100^{\text {th }}$ Anniversary of "Oka Flora” by A. F. Flerov, May 23-28, 2010, Ryazan, Ryazan State University Named for S. Yesenin, 234-242 [In Russian].

Pospelova, E. B.; Pospelov, I. N., 2007, Vascular Flora of Taimyr Peninsula and Neighboring Territories, Part 1,
Annotated List of Flora and Its Common Analysis, Moscow, KMK Scientific Press Ltd. [In Russian].

Tolmachyov, A. I., 1974, Introduction to Plant Geography, Leningrad, Leningrad University [In Russian].

Yurtsev, B.A., 1968, Flora of Suntar-Chayata: the Problem of the History of Highland Landscapes in the NorthEast of Siberia, Leningrad, Nauka [In Russian].

Yurtsev, B.A., 1981, Relic Steppe Complexes of Northeast Asia, Novosibirsk, Nauka [In Russian].

Yurtsev, B. A., 1991, Problems of Distinguishing the Tundra Type of Vegetation, Botanicheskii Zhurnal, 46, 1, 30-41 [In Russian].

Yurtsev, B. A.; Kamelin, R. V., 1991, Basic Concepts and Terms of Floristics, Perm, Perm University [In Russian]. 